\title{
Determination of Optimal Roasting Conditions for the Production of Gabou
}

\author{
Maman M. Rabiou ${ }^{1}$, Chaibou Yaou ${ }^{1}$, Mamadou Lewamy ${ }^{1}$, Idrissa Moussa ${ }^{1}$, Haoua Sabo ${ }^{1} \&$ Hassimi Sadou $^{1}$ \\ ${ }^{1}$ Department of Chemistry, Faculty of Science and Technology, Abdou Moumouni University, BP: 10662. \\ Niamey. Niger \\ Correspondence: Maman M. Rabiou, Department of Chemistry, Faculty of Science and Technology, Abdou \\ Moumouni University, BP: 10662. Niamey. Niger. Tel: 227-9703-6626. E-mail: Rabiouitina@gmail.com
}

Received: June 4, 2019

doi:10.5539/jfr.v8n5p48
Accepted: June 21, 2019 Online Published: August 8, 2019

URL: https://doi.org/10.5539/jfr.v8n5p48

\begin{abstract}
Gabou is a traditional onion-based spice commonly used in Niger. It is prepared in a handcrafted way by roasting of dried onion. This study was conducted to determine the optimal roasting conditions. The traditional processes of Gabou manufacturing were identified through a survey and studied. Gabou were produced at different roasting temperatures and times in presence of the oil quantities in the laboratory. Then sensory analyses were conducted to select the Gabou of best sensory characteristics. The chemical composition of the selected Gabou and their raw materials was determined. The result of the investigation showed that flower stems, green leaves and onion bulbs were used in the production of Gabou. The optimal roasting conditions were obtained at $120^{\circ} \mathrm{C}$ for $8 \mathrm{~min}$ for bulbs Gabou, $120^{\circ} \mathrm{C}$ for $5 \mathrm{~min}$ for green leaves Gabou and $130^{\circ} \mathrm{C}$ for $11 \mathrm{~min}$ for flower stems Gabou in the presence of $1 \mathrm{ml}, 2 \mathrm{ml}$ and $0 \mathrm{ml}$ palm oil per $30 \mathrm{~g}$, respectively. Roasting conditions that led to the production of Gabou of good sensory characteristics did not have a significant negative influence $(\mathrm{p}<0.05)$ on proximate and mineral composition. On the contrary, they have significantly reduced the moisture content which contributes to the reduction of Gabou shelf life.
\end{abstract}

Keywords: Gabou, spice, onion, roasting, sensory characteristics, proximate composition

\section{Introduction}

Onion (Allium cepa L. var. cepa,) is a herbaceous monocotyledon belonging to the family of alliaceae native of the Central Asia (Fritsch \& Friesen, 2002). It is constituted by a plateau on which are inserted elongated green leaves, cylindrical and hollow and from which adventitious roots leave. The upright floral stem is also hollow. The base of the leaves may bulge when conditions are favorable and form a bulb. Onion bulb is composed of fleshy leaves and is externally covered with one or more layers of dried leaves that are also called tunics (Foury $\&$ Schweisguth, 1992). Inside the leaves, we find the terminal bud. Onion was first exploited as a medicinal plant before becoming a seasoning ingredient or vegetable (De Lannoy, 2001).

With an annual production of 711964 tons (Ministry of agriculture [MA], 2013), Niger was the second largest onion producer in West Africa behind Nigeria (D'Alessandro \& Soumah, 2008). The sector generates 47 billion CFA francs (72 million Euros) (Boukary et al., 2012). It is a very important source of income (Tarchiani, Robbiati, \& Salifou, 2013). Despite the fact that this speculation is considered as an emerging sector, there are problems related to the strong seasonality of supply and the inabilities to spread the marketing. Indeed the crops remain concentrated between the months of February, March and April (Rabiou, Moussa, Mella, \& Sadou, 2018a; Project for the Development of exports and Agro-Sylvo Pastoral markets [PRODEX], 2009). Thus, supply becomes very important, leading to sharp price decreases on the markets. Fluctuations in prices, especially during periods of high production, lead to losses of around 50,000 tons, or nearly $25 \%$ of production in the area, leading to a shortfall of nearly 1 billion CFA francs on the whole of the sector. In addition there are problems of storage and conservation of the product, the direct consequence of which is the loss of the crop by rotting (PRODEX, 2012). Indeed, 30\% of the production is lost because of the storage problem is more than 6 billion CFA francs (Eplucher oignon, 2010). Given its strong contribution to the national economy and the numerous post-harvest losses recorded each year, it is urgent to enhance the value of onion sector through appropriate support measures. Gabou production could be one of the ways to enhance the value of the onion sector in Niger.

Gabou is a traditional spice obtained by the transformation of onion. It is used in both rural and urban areas in 
the preparation of sauces (Rabiou et al., 2018a; Rabiou, Yaou, Lewamy, \& Sadou, 2018b). However, the sensory quality of Gabou varies from one producer to another. This is mainly due to the roasting conditions. The aim of this study was to determine the optimal roasting conditions for the production of Gabou.

In our research project, first, we surveyed onion production conditions in the study area (Rabiou et al., 2018a). Then, we determined the chemical composition of different types of Gabou as well as their raw materials obtained from renowned Gabou producers (Rabiou et al., 2018b). During the present study, we identified the different traditional Gabou manufacturing processes in the study areas and, under the conditions of the laboratory; we researched the good combination of roasting time and temperature that gives a Gabou of best sensory quality.

\section{Materials and Methods}

The study was conducted at Abdou Moumouni University, during 12 months, starting from March, 2018 to March, 2019.

\subsection{Plant Material}

The plant material consisted of flower stems, green leaves and bulbs of onion supplied in the commune of Sakoira. The variety of onion used is called 'Gothèye white'. Its bulb of strong and pungent flavor is white, spherical in shape with several lobes such as shallot or even garlic. Its elongated green leaves and upright flower stems are cylindrical and hollow.

\subsection{Methods}

\subsubsection{Study Area, Sample Size and Data Collection}

Two sites known for the quality of their Gabou were the subject of the investigation. These were the commune of Sakoira and the department of Gothèye, all located in the region of Tillabéry (latitudes $11^{\circ} 50$ and $15^{\circ} 45$ East and longitudes $0^{\circ} 10$ and $4^{\circ} 20$ East). The methodology adapted was open surveys and follow-up with Gabou women producers. The choice of these producers was random. A total of seventy-five (75) women producers were surveyed, 15 of whom were followed during the production of Gabou.

\subsubsection{Oven Drying}

The vegetative parts of the onion were carefully washed and cut into pieces before drying. Thus, the flower stems were cut into small pieces about $3 \mathrm{~cm}$ long, the green leaves were lightly crushed in a mortar and the onion bulbs were cut into small pieces after being peeled and dried in an oven first at $65^{\circ} \mathrm{C}$ and then when their water content decreased significantly, the temperature was reduced to $50^{\circ} \mathrm{C}$. Roasting tests were conducted on these three dried products, namely flower stem pieces, crushed green leaves and small pieces of onion bulbs.

\subsubsection{Oven Roasting}

Roasting was carried out on flower stems, green leaves and onion bulbs. $30 \mathrm{~g}$ of dry plant material were roasted at $110^{\circ} \mathrm{C}$ for 5,8 and $11 \mathrm{~min}$ and, in the presence of $0,1,2$ or $3 \mathrm{ml}$ of palm oil. The same operation was repeated at 120 and $130{ }^{\circ} \mathrm{C}$. The products (Gabou) obtained were subjected to sensory evaluation. Then, physicochemical analyses were carried out on Gabou that had good sensory characteristics, in particular aroma and color.

\subsubsection{Sensory Analysis}

The sensory analysis was carried out to determine the degree of appreciation of the aroma and color of the Gabou obtained from different heat treatments. According to the method described by Mendes et al. (2001), a 9-point hedonic scale ranging from not extremely fond to extremely fond was used. The sensory analysis was applied in an environmentally controlled room under white fluorescent light. The sensory analysis was carried out with 40 assessors, 5 men and 35 women aged 17 to 50 years (Watts, Ylimaki, Jeffery, \& Elias, 1991). They were selected on the basis of their interest in participating in the sensory analysis panel but also on their knowledge of the product, and all panelists were given instructions on how to complete the form and how the test would be conducted. Four (4) samples of $5 \mathrm{~g}$ in a jar coded by three-letter were randomly presented to the panelists.

\subsubsection{Proximate Analysis}

The moisture, ash, crude fiber, proteins and fat of flower stems, green leaves and bulbs of onion were determined and compared respectively to their by-product (Gabou) which presented the best sensory characteristics (AOAC, 1999).Total carbohydrates were estimated by difference. Energy was calculated according to the following equation: Energy $(\mathrm{kcal})=(\%$ proteins $\mathrm{x} 4)+(\%$ carbohydrates $\mathrm{x} 4)+(\%$ lipids $\mathrm{x} 9)$. The $\mathrm{pH}$ was measured using a $\mathrm{pH}$ meter on a homogenate of $10 \mathrm{~g}$ sample in $90 \mathrm{~mL}$ distilled water (AOAC, 2000). The results of ash, fiber, 
protein, lipid and carbohydrate contents were expressed on dry matter basis.

\subsubsection{Mineral Analysis}

The ashes were solubilized in hydrochloric acid. The contents of $\mathrm{Ca}, \mathrm{Mg}$ and $\mathrm{Zn}$ were determined by atomic absorption spectrophotometry, Na and K by emission spectrophotometry (AOAC, 1999). Analyzes were made in triplicate and the results were reported in relation to the dry matter.

\subsubsection{Statistical Analyses}

The statistical analyses were performed using Minitab 16. Sensory evaluation and physicochemical analysis data were subjected to an analysis of variance (ANOVA) and averages compared using the Tukey test. The differences were considered significant at $\mathrm{P}<0.05$.

\section{Results}

\subsection{Characteristics of Onion Traditional Processing into Gabou}

\subsubsection{Profile of Gabou Producers}

The investigation revealed that Gabou production was an exclusively female activity. Most of these producers were initiated to this activity by their parents. All the women producers surveyed did not receive any training on the rules of hygiene and unit operations from public authorities or non-governmental organizations. A better valorization of Gabou passed necessarily by the training of the producers on the rules of hygiene, drying techniques, roasting and packaging.

\subsubsection{Description of the Traditional Technological Processes of Gabou Manufacturing}

After harvesting onion plant, the green leaves, flower stems and bulbs were separated using a knife. All parts were used in the production of Gabou. The green leaves and the flower stems were each transformed into a single type of Gabou. The bulb can give up to four types of Gabou.

\subsubsection{Gabou of Onion Bulbs}

Some producers used the whole bulb to produce bulbs' Gabou. However, others produced up to three types of Gabou from onion bulb. The buds were used to produce Gabou-Izé, the fleshy leaves of Gabou Koirey and the peelings (parched superficial leaves) of Gabou Feto-Feto.

Crushing: It was the first unitary operation of bulb Gabou manufacturing. Crushing was the common step for all four types of bulb Gabou. It allowed to reduce the size of the bulb in order to reduce the drying time and facilitate the separation of the different parts. The bulb was crushed between two stones of different size. The bud was ejected and the bulb's fleshy leaves remaining were softened. Certain producers dried buds and fleshy leaves separately whereas others dried them together.

\section{$>$ Gabou of whole bulb}

Drying: It was conducted to reduce the water content of these raw materials of Gabou in order to increase the conservation period. The product obtained was dried on the ground under the sun for about 17 days depending on the weather. The dried product was either left at drying or packed in polyethylene bags. Some small quantifies were taken, roasted and marketed.

Sorting: it was conducted in order to render the dried product most hygienic. For that vegetable debris, sand grains and badly dried buds and fleshy leaves were removed.

Roasting: roasting allowed the development of Gabou aroma. It also led to more thorough desiccation, which facilitates crushing by shelling. The dried and sorted product was roasted in a pot until release of the characteristic aroma. Some producers add, from time to time, small amounts of oil during roasting.

\section{Gabou of bulbs buds: Gabou Izé}

Drying: After crushing the bulbs, the buds were collected, spread on a plastic or tarpaulin and placed in the drying under the sun for about 15 days. They were turned once or twice by day.

Sorting: Manual sorting was done according to the size and quality of the dried buds. These sorts allowed to eliminate bud debris and badly dried buds. These badly dried buds were characterized by a brown color. Badly dried buds were usually in direct contact with the tarpaulin or plastic. After sorting, the buds were packed in polyethylene or polypropylene bags where small quantities were taken as needed for roasting.

Roasting: The dried buds were roasted in a pot, adding a few drops of oil from time to time, until release of the characteristic aroma. Roasting was stopped when the buds began to emit a characteristic aroma. 


\section{Gabou of bulbs fleshy leaves: Gabou Koirey}

Drying: The fleshy leaves from the bulb crushing were collected and spread on the roofs of the houses, on the ground, and left to dry under the sun for 8 to 10 days depending on the weather.

Peeling: After drying, the peels were removed by hand. The peeled fleshy leaves were packed in polyethylene bags or left at their drying place. From time to time small quantities were picked and roasted according to needed.

Roasting: Dried fleshly leaves were then roasted in a pot, adding a few drops of oil from time to time, until release of the characteristic aroma.

\section{$>$ Gabou of bulbs peels: Gabou Feto-Feto}

The peels obtained by peeling the dried fleshy leaves were combined and then roasted. Consumers of Gabou Feto-Feto were essentially poor rural households. The unit operations of the production of these four types of Gabou were summarized in figure 1.

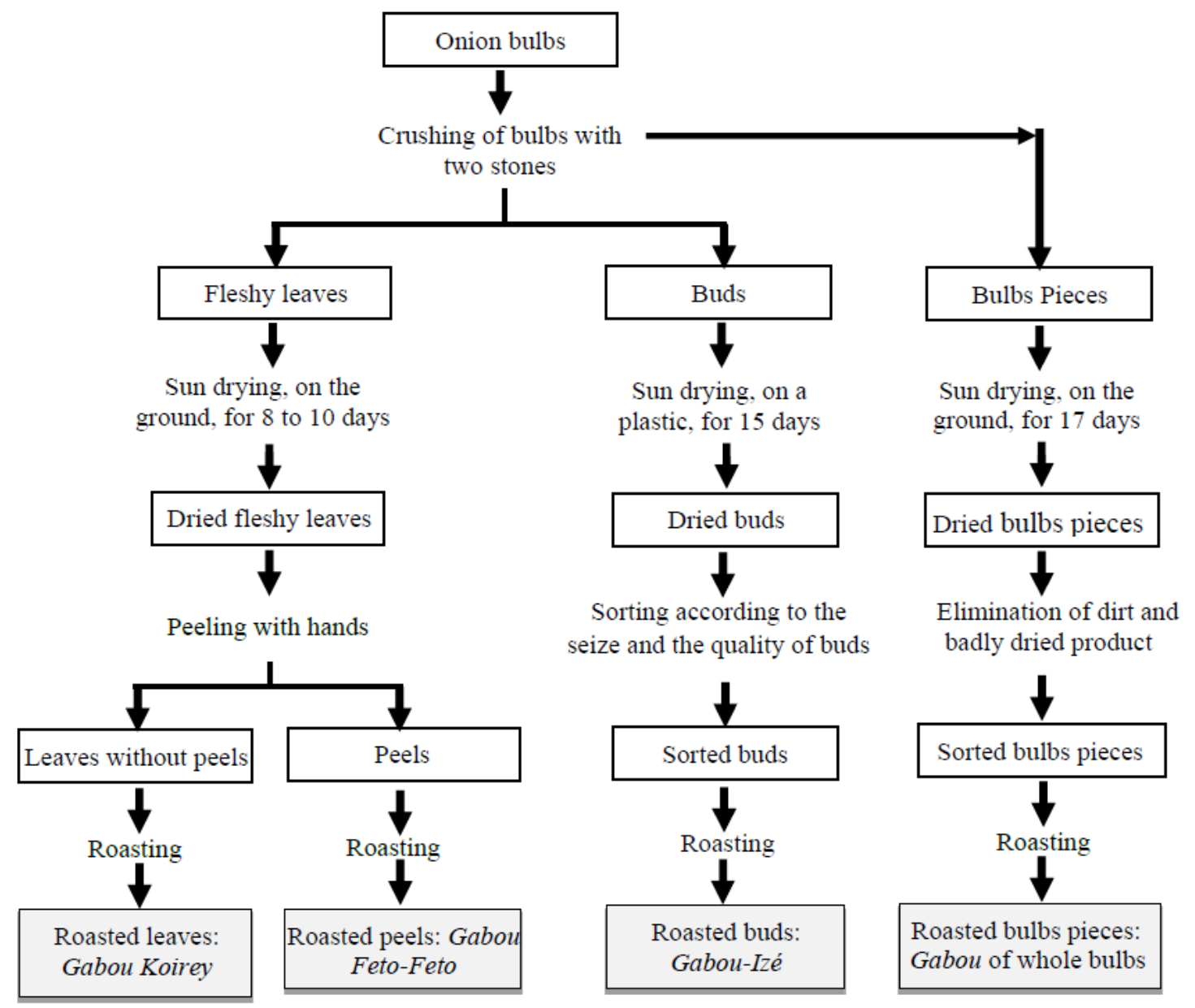

Figure 1. Diagram of traditional processes of making Gabou-Izé, Gabou Koirey, Gabou Feto-Feto and Gabou of whole bulb

\subsubsection{Gabou of Onion Green Leaves: Gabou-Bi}

The traditional process of onion green leaves Gabou manufacturing was summarized in three (3) major unit operations (Figure 2):

Grinding: The fresh leaves were slightly crushed by pounding in a wooden mortar.

Drying: The slightly crushed leaves were dried on the ground, under the sun for 2 to 3 days.

Roasting: After drying, the crushed leaves were roasted in a pot, adding a small amount of oil, until release of the characteristic aroma. 


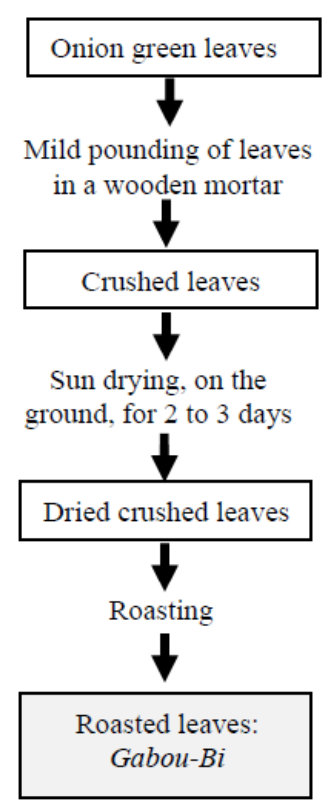

Figure 2. Diagram of traditional process of making onion green leaves Gabou (Gabou-Bi)

\subsubsection{Gabou of Onion Flower Stems: Gabou For-Foro}

The traditional process of onion flower stems Gabou manufacturing was summarized in three major unit operations presented in Figure 3.

Cutting: the flower stems were first cut into small pieces of 1 to $3 \mathrm{~cm}$ with a knife.

Drying: the pieces obtained after cutting were dried under sun in the open air on a tarpaulin for 2 to 3 days.

Roasting: the pieces of the dried stems were roasted in a pot until release of the characteristic aroma. During this operation, small amount of oil was added.

According to the producers, the ranking in decreasing order of the taste of Gabou was: Gabou Izé, Gabou Koirey, Gabou For-Foro, Gabou-Bi and Gabou Feto-Feto. Whereas the ranking in descending order of the aroma of Gabou was: Gabou For-Foro, Gabou Izé, Gabou Koirey, Gabou-Bi, and Gabou Feto-Feto. The diagram below showed the traditional process of onion flower stems Gabou manufacturing.

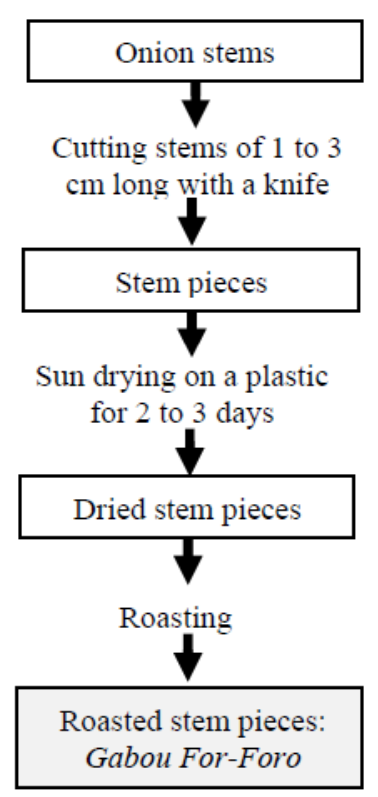

Figure 3. Diagram of traditional process of making flower stems Gabou (Gabou For-Foro) 


\subsubsection{Formulation of Gabou : Gabou Hamni}

Gabou Hamni is the condiment form of Gabou. It is a powder formulated from 3 to 5 types of Gabou with roasted sesame. Gabou Hamni depends on the desired taste and aroma. The different types of Gabou were measured according to the desired proportions. The whole was introduced into a mortar and then crushed. The fine and coarse powder obtained was sieved with a mesh sieve of approximately $200 \mu \mathrm{m}$. The grinding and sieving operations were repeated several times until complete transformation of the sieving residues into fine powder. The diagram below presented the traditional processes of making Gabou Hamni (Figure 4).

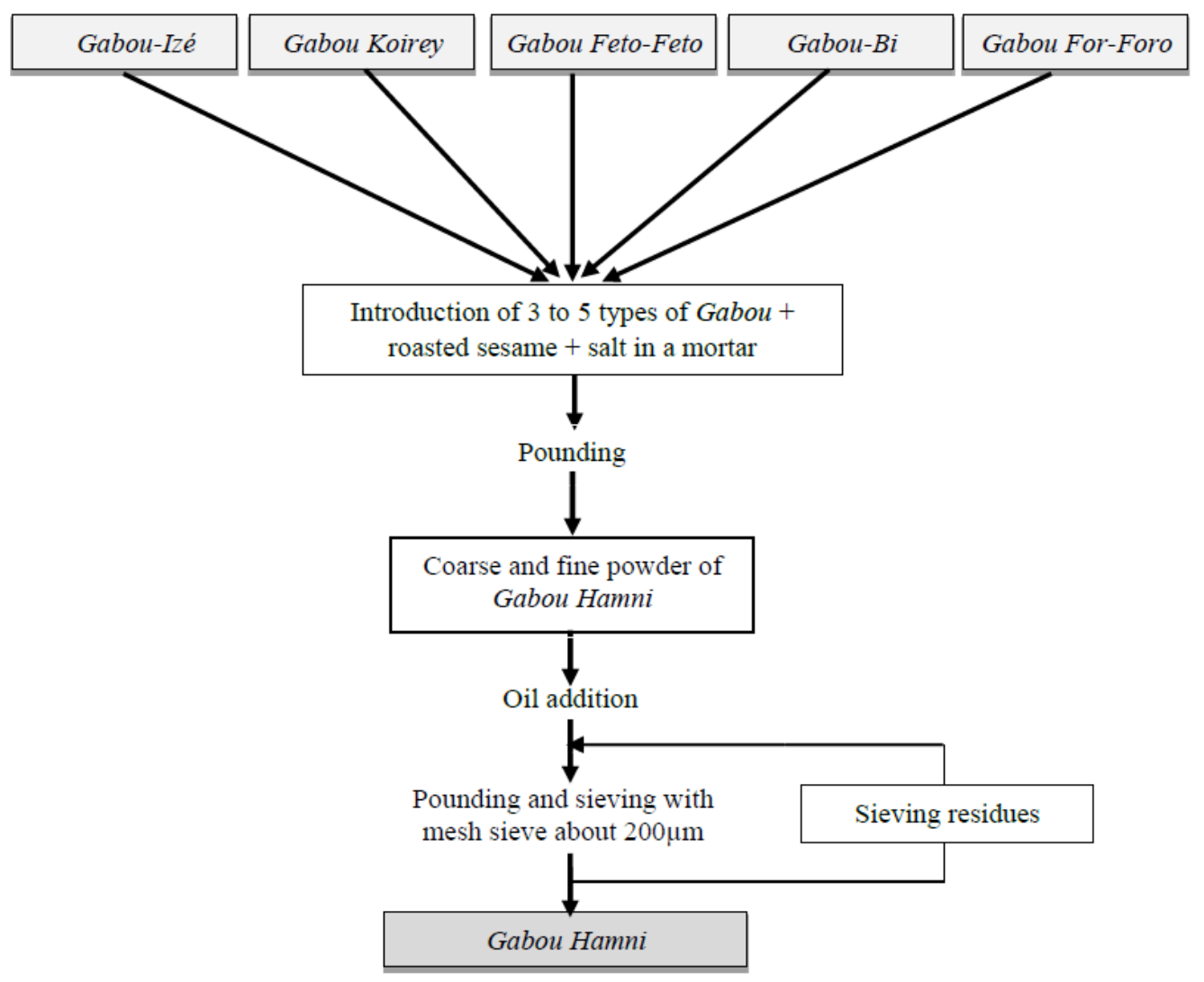

Figure 4. Diagram of traditional process of making Gabou Hamni

\subsubsection{Difficulties Related to the Production of Gabou}

Producers encounter many difficulties during the production of Gabou. Indeed the lack of necessary equipment makes Gabou production a tedious and time-consuming activity. This is not inconsequential since it competes with usual household work. The result of the investigation showed that the producers were unanimous that Gabou production from onion bulbs was more difficult than its production from the green leaves and flower stems. According to the producers, the classification of the unit operations of Gabou production by order of decreasing difficulties were crushing of bulbs (with the help of two stones) exposing them to gases, roasting exposing them to heat and curvature, light grinding with mortar of green leaves tires them physically and finally drying consumes them a lot of time because of the coming and goings to turn the product or move it. In addition to this, we note the rarity or rupture of onion on the markets causing a rise in its price just a few months after the harvest. For that, the producers longed for financial support to buy, dry and store enough onion during the harvest period.

\subsection{Determination of Optimal Roasting Conditions}

\subsubsection{Effect of Roasting Conditions on the Sensory Characteristics of Gabou}

Aroma and color scores of the Gabou obtained under different heat treatments were grouped in Table 1. The results showed that the different combinations (temperature, time and quantity of oil) led to the production of Gabou with significantly different $(\mathrm{p}<0.05)$ sensory characteristics (aroma and color). The highest aroma score 
of the flower stem Gabou was obtained, when the slices of about $3 \mathrm{~cm}$ of floral stems were roasted at $130^{\circ} \mathrm{C}$ for 11 min without adding of oil. Concerning the color of the flower stem Gabou, the highest score was obtained when the flower stem slices were roasted at $120^{\circ} \mathrm{C}$ for $11 \mathrm{~min}$ in the presence of $1 \mathrm{ml}$ of oil in $30 \mathrm{~g}$. For green leaves Gabou, the largest aroma and color scores were obtained, when the dried green leaves were roasted at $120^{\circ} \mathrm{C}$ for $5 \mathrm{~min}$ in the presence of $2 \mathrm{ml}$ of oil per $30 \mathrm{~g}$. Finally, the onion bulbs Gabou had the highest scores, for aroma and color, when the small pieces of dried bulbs were roasted at $120^{\circ} \mathrm{C}$ for $8 \mathrm{~min}$ in the presence of $1 \mathrm{ml}$ of oil per $30 \mathrm{~g}$.

Table 1. Mean sensory scores for the aroma and color of the different types of Gabou obtained by differential heat treatments*

\begin{tabular}{|c|c|c|c|c|c|c|c|c|c|c|}
\hline \multirow{3}{*}{$\begin{array}{l}\text { Plant material } \\
(30 \mathrm{~g})\end{array}$} & \multirow{3}{*}{$\begin{array}{l}\text { Temperature } \\
\left({ }^{\circ} \mathrm{C}\right)\end{array}$} & Aroma & \multicolumn{7}{|c|}{ Color } & \multirow{3}{*}{$\begin{array}{l}\text { Time } \\
(\min )\end{array}$} \\
\hline & & \multicolumn{4}{|l|}{ Oil (mL) } & \multicolumn{4}{|l|}{ Oil (mL) } & \\
\hline & & 0 & 1 & 2 & 3 & 0 & 1 & 2 & 3 & \\
\hline \multirow{6}{*}{$\begin{array}{l}\text { Gabou of } \\
\text { flower stems }\end{array}$} & \multirow[t]{3}{*}{120} & $3.41 \pm 0.24 \mathrm{~m}$ & $3.62 \pm 0.49 \mathrm{~m}$ & $3.46 \pm 0.368 \mathrm{~m}$ & $3.31 \pm 0.24 \mathrm{~m}$ & $5.50 \pm 2.55 \mathrm{bc}$ & $5.50 \pm 2.55 \mathrm{bc}$ & $5.50 \pm 2.55 \mathrm{bc}$ & $5,50 \pm 2,55 \mathrm{bc}$ & 5 \\
\hline & & $5.25 \pm 0.98 \mathrm{ik}$ & $4.93 \pm 0.73 \mathrm{kl}$ & $4.62 \pm 0.491$ & $4.50 \pm 0.501$ & $5.00 \pm 1.02 \mathrm{bcd}$ & $5.25 \pm 1.27 \mathrm{bc}$ & $5.50 \pm 1.53 \mathrm{bcd}$ & $6,00 \pm 2,04 \mathrm{ab}$ & 8 \\
\hline & & $5.87 \pm 0.88 \mathrm{ghi}$ & $5.87 \pm 0.88 \mathrm{ghi}$ & $5.75 \pm .75 \mathrm{hij}$ & $5.50 \pm 0.50 \mathrm{ij}$ & $7.50 \pm 2.55 \mathrm{a}$ & $6.75 \pm 1.79 \mathrm{ab}$ & $6.62 \pm 1.66 \mathrm{ab}$ & $6,25 \pm 1,27 \mathrm{ab}$ & 11 \\
\hline & \multirow[t]{3}{*}{130} & $6.50 \pm 0.50 \mathrm{def}$ & $6.37 \pm 0.37 \mathrm{efg}$ & $6.12 \pm 0.12 \mathrm{fgh}$ & $6.12 \pm 0.12 \mathrm{fgh}$ & $6.50 \pm 0.51 \mathrm{ab}$ & $6.0 \pm 0.00 \mathrm{ab}$ & $5.87 \pm 0.12 \mathrm{ab}$ & $5,50 \pm 0,51 \mathrm{bc}$ & 5 \\
\hline & & $7.25 \pm 0.25 b c$ & $7.12 \pm 0.12 \mathrm{bc}$ & $6.50 \pm 0.50 \mathrm{def}$ & $6.75 \pm 0.25 \mathrm{cde}$ & $5.75 \pm 1.27 \mathrm{abc}$ & $5.00 \pm 2.04 \mathrm{bcde}$ & $5.00 \pm 2.04 \mathrm{bcde}$ & $5,00 \pm 2,04 \mathrm{bcde}$ & 8 \\
\hline & & $7.87 \pm 0.12 \mathrm{a}$ & $7.50 \pm 0.50 \mathrm{ab}$ & $7.00 \pm 1.01 \mathrm{bcd}$ & $6.50 \pm 1.51 \mathrm{def}$ & $4.0 \pm 1.02 \mathrm{cdef}$ & $3.50 \pm 0.5 \mathrm{def}$ & $3.2 \pm 0.25 \mathrm{ef}$ & $2,50 \pm 0,51 \mathrm{f}$ & 11 \\
\hline \multirow{9}{*}{$\begin{array}{l}\text { Gabou of } \\
\text { green leaves }\end{array}$} & \multirow[t]{3}{*}{110} & $3.37 \pm 0.63 \mathrm{jklm}$ & $3.50 \pm 0.50 \mathrm{ijkl}$ & $3.75 \pm 0.25 \mathrm{ijk}$ & $3.87 \pm 0.12 \mathrm{ij}$ & $3.00 \pm 1.011$ & $3.00 \pm 1.011$ & $3.25 \pm 0.76 \mathrm{kl}$ & $3,50 \pm 0,50 \mathrm{jkl}$ & 5 \\
\hline & & $4.50 \pm 0.50 \mathrm{gh}$ & $4.75 \pm 0.25 \mathrm{fg}$ & $4.87 \pm 0.12 \mathrm{fg}$ & $4.50 \pm 1.51 \mathrm{gh}$ & $4.00 \pm 1.01 \mathrm{hij}$ & $4.00 \pm 1.01 \mathrm{hij}$ & $4.50 \pm 0.50 \mathrm{fgh}$ & $4,50 \pm 0,50 \mathrm{fgh}$ & 8 \\
\hline & & $4.75 \pm 1.2 \mathrm{fg}$ & $5.00 \pm 1.01 \mathrm{efg}$ & $5.00 \pm 1.01 \mathrm{efg}$ & $5.12 \pm 0.12 \mathrm{ef}$ & $5.50 \pm 0.50 \mathrm{de}$ & $5.50 \pm 0.50 \mathrm{de}$ & $6.00 \pm 0.00 \mathrm{~cd}$ & $5,50 \pm 0,50 \mathrm{de}$ & 11 \\
\hline & \multirow[t]{3}{*}{120} & $5.87 \pm 0.12 \mathrm{~cd}$ & $6.37 \pm 0.37 \mathrm{bc}$ & $7.25 \pm 0.25 \mathrm{a}$ & $6.50 \pm 0.50 \mathrm{~b}$ & $6.50 \pm 0.50 \mathrm{bc}$ & $6.87 \pm 0.12 b$ & $7.75 \pm 0.25 \mathrm{a}$ & $7,00 \pm 0,00 \mathrm{~b}$ & 5 \\
\hline & & $5.50 \pm 0.50 \mathrm{de}$ & $5.50 \pm 0.50 \mathrm{df}$ & $5.75 \pm 0.75 \mathrm{~d}$ & $5.87 \pm 0.88 \mathrm{~cd}$ & $6.12 \pm 0.12 \mathrm{c}$ & $6.25 \pm 0.25 \mathrm{c}$ & $6.25 \pm 0.25 \mathrm{c}$ & $6,50 \pm 0,50 \mathrm{bc}$ & 8 \\
\hline & & $4.50 \pm 0.50 \mathrm{gh}$ & $4.87 \pm 0.88 \mathrm{fg}$ & $4.50 \pm 0.50 \mathrm{hg}$ & $4.50 \pm 0.50 \mathrm{gh}$ & $5.00 \pm 0.00 \mathrm{ef}$ & $5.50 \pm 0.50 \mathrm{de}$ & $4.50 \pm 0.50 \mathrm{fgh}$ & $4,75 \pm 0,25 \mathrm{fg}$ & 11 \\
\hline & \multirow[t]{3}{*}{130} & $3.37 \pm 0.37 \mathrm{ijklm}$ & $3.50 \pm 0.50 \mathrm{ijkl}$ & $3.75 \pm 0.75 \mathrm{ijk}$ & $4.00 \pm 1.01 \mathrm{hi}$ & $3.87 \pm 0.12 \mathrm{ij}$ & $4.00 \pm 0.00 \mathrm{hij}$ & $4.25 \pm 0.25 \mathrm{ghi}$ & $4,50 \pm 0,50$ fgh & 5 \\
\hline & & $3.00 \pm 1.01 \mathrm{lmno}$ & $3.12 \pm 1.13 \mathrm{lmr}$ & $3.25 \pm 1.26 \mathrm{klm}$ & $1 \mathrm{n} 3.40 \pm 1.41 \mathrm{jkln}$ & $3.50 \pm 0.50 \mathrm{jkl}$ & $3.62 \pm 0.63 \mathrm{jk}$ & $3.87 \pm 0.88 \mathrm{ij}$ & $4,00 \pm 1,01 \mathrm{hij}$ & 8 \\
\hline & & $2.50 \pm 0.50 \mathrm{o}$ & $2.60 \pm 0.50 \mathrm{o}$ & $2.75 \pm 0.25 \mathrm{no}$ & $2.87 \pm 0.12 \mathrm{mn}$ & $3.50 \pm 0.50 \mathrm{jkl}$ & $3.75 \pm 0.25 \mathrm{ijk}$ & $4.00 \pm 1.01 \mathrm{hij}$ & $3,50 \pm 1,52 \mathrm{jkl}$ & 11 \\
\hline \multirow{9}{*}{$\begin{array}{l}\text { Gabou of } \\
\text { onion bulbs }\end{array}$} & \multirow[t]{3}{*}{110} & $3.50 \pm 0.5270 \mathrm{~g}$ & $3.60 \pm 0.527 \mathrm{~g}$ & $3.87 \pm 0.922 \mathrm{fg}$ & $3.80 \pm 0.92 \mathrm{fg}$ & $3.00 \pm 0.83 n$ & $3.16 \pm 0.63 \mathrm{mn}$ & $3.33 \pm 0.48 \mathrm{mn}$ & $3,50 \pm 0,41 \mathrm{lmn}$ & 5 \\
\hline & & $4.40 \pm 0.52 \mathrm{f}$ & $4.50 \pm 0.52 \mathrm{f}$ & $4.50 \pm 0.52 \mathrm{f}$ & $4.300 \pm 0.52 \mathrm{f}$ & $4.33 \pm 0.48 \mathrm{ijkl}$ & $4.58 \pm 0.43 \mathrm{ij}$ & $4.66 \pm 0.48 \mathrm{ij}$ & $4,75 \pm 0,55 \mathrm{hij}$ & 8 \\
\hline & & $5.50 \pm 0.527 \mathrm{e}$ & $5.65 \pm 0.527 \mathrm{e}$ & $5.70 \pm 0.527 \mathrm{e}$ & $5.40 \pm 0.527 \mathrm{e}$ & $5.58 \pm 0.43 \mathrm{fgh}$ & $5.66 \pm 0.48 \mathrm{fg}$ & $5.93 \pm 0.75 \mathrm{ef}$ & $6,00 \pm 0,83 \mathrm{ef}$ & 11 \\
\hline & \multirow[t]{3}{*}{120} & $5.50 \pm 0.52 \mathrm{e}$ & $6.50 \pm 0.52 \mathrm{~cd}$ & $6.60 \pm 0.52 \mathrm{~cd}$ & $6.25 \pm 0.26 \mathrm{cde}$ & $6.66 \pm 0.48 \mathrm{bcd}$ & $6.75 \pm 0.55 \mathrm{bcde}$ & $6.91 \pm 0.73 \mathrm{bcd}$ & $7,00 \pm 0,83 \mathrm{bcd}$ & 5 \\
\hline & & $6.50 \pm 0.52 \mathrm{~cd}$ & $8.50 \pm 0.52 \mathrm{a}$ & $7.50 \pm 0.52 \mathrm{~b}$ & $7.00 \pm 1.05 b c$ & $7.50 \pm 0.41 \mathrm{ab}$ & $8.00 \pm 0.83 \mathrm{a}$ & $7.33 \pm 0.96 \mathrm{ab}$ & $7,16 \pm 0,86 a b c$ & 8 \\
\hline & & $6.00 \pm 1.05 \mathrm{de}$ & $6.50 \pm 0.52 \mathrm{~cd}$ & $6.75 \pm 0.26 \mathrm{bcd}$ & $6.50 \pm 0.52 \mathrm{~cd}$ & $6.00 \pm 0.83 \mathrm{ef}$ & $6.33 \pm 0.96 \mathrm{cdef}$ & $6.16 \pm 0.86 \mathrm{def}$ & $5,66 \pm 0,96 \mathrm{fg}$ & 11 \\
\hline & \multirow[t]{3}{*}{130} & $5.50 \pm 0.52 \mathrm{e}$ & $6.25 \pm 0.26 \mathrm{cde}$ & $6.30 \pm 0.26 \mathrm{cde}$ & $5.50 \pm 0.52 \mathrm{e}$ & $5.00 \pm 0.83 \mathrm{ghi}$ & $5.00 \pm 0.83 \mathrm{ghi}$ & $4.90 \pm 0.86 \mathrm{ghij}$ & $4,83 \pm 0,89$ ghij & 5 \\
\hline & & $5.50 \pm 0.52$ & $6.50 \pm 0.52 \mathrm{~cd}$ & $6.50 \pm 0.52 \mathrm{~cd}$ & $5.50 \pm 0.52 \mathrm{e}$ & $4.33 \pm 1.27 \mathrm{ijkl}$ & $4.50 \pm 1.10 \mathrm{ijk}$ & $4.66 \pm 0.96 \mathrm{ij}$ & $4,00 \pm 1,66 \mathrm{ijklm}$ & 8 \\
\hline & & $4.50 \pm 0.52 \mathrm{f}$ & $5.50 \pm 0.52 \mathrm{e}$ & $5.50 \pm 0.52 \mathrm{e}$ & $5.50 \pm 0.52 \mathrm{e}$ & $3.60 \pm 1.45 \mathrm{klmr}$ & $3.80 \pm 1.30 \mathrm{klmr}$ & $3.78 \pm 1.27 \mathrm{klmr}$ & r. $3,65 \pm 1,20 \mathrm{klmn}$ & 11 \\
\hline
\end{tabular}

For each Gabou and for each attribute, there is no significant difference ( $>>0.05)$ between the means that have the same letter on each line. * Significant difference was found between the aroma of the dried flower stems and its Gabou obtained at $110^{\circ} \mathrm{C}$ by the panelists.

\subsubsection{Effect of Roasting Conditions on the Proximate Composition of Gabou}

The proximate composition and energy values of dried flower stems, green leaves, bulbs and their by-product (Gabou) are presented in Table 2.

Table 2. Proximate composition expressed in $\mathrm{g} / 100 \mathrm{~g}$ and energy value $(\mathrm{Kcal} / 100 \mathrm{~g})$ of dried vegetative parts of onion and Gabou

\begin{tabular}{llllllll}
\hline Products & Moisture & Ash & Lipids & Proteins & Carbohydrates & Fibers & Energy \\
\hline Flower stems & $8.70 \pm 0.02 \mathrm{~b}$ & $8.34 \pm 0.03 \mathrm{~b}$ & $1.48 \pm 0.02 \mathrm{c}$ & $8.15 \pm 0.08 \mathrm{~d}$ & $59.28 \pm 0.10 \mathrm{e}$ & $14.02 \pm 0.00 \mathrm{~b}$ & $283.13 \pm 0.10 \mathrm{e}$ \\
Gabou of flower stems & $2.80 \pm 0.02 \mathrm{~d}$ & $8.54 \pm 0.05 \mathrm{~b}$ & $1.62 \pm 0.03 \mathrm{c}$ & $7.95 \pm 0.06 \mathrm{~d}$ & $66.00 \pm 0.06 \mathrm{c}$ & $13.08 \pm 0.15 \mathrm{bc}$ & $310.45 \pm 0.17 \mathrm{~d}$ \\
Green leaves & $9.62 \pm 0.26 \mathrm{a}$ & $18.01 \pm 1.05 \mathrm{a}$ & $3.92 \pm 0.10 \mathrm{~b}$ & $17.91 \pm 0.03 \mathrm{a}$ & $33.74 \pm 0.07 \mathrm{~g}$ & $16.85 \pm 0.23 \mathrm{a}$ & $241.94 \pm 0.81 \mathrm{~g}$ \\
Gabou of green leaves & $3.56 \pm 0.31 \mathrm{c}$ & $17.4 \pm 0.06 \mathrm{a}$ & $3.97 \pm 0.03 \mathrm{~b}$ & $17.62 \pm 0.31 \mathrm{a}$ & $41.68 \pm 1.21 \mathrm{f}$ & $16.03 \pm 0.04 \mathrm{a}$ & $273.02 \pm 6.41 \mathrm{f}$ \\
Onion bulbs & $8.48 \pm 0.20 \mathrm{~b}$ & $3.31 \pm 0.24 \mathrm{~d}$ & $0.85 \pm 0.07 \mathrm{~d}$ & $10.51 \pm 0.08 \mathrm{c}$ & $72.73 \pm 0.35 \mathrm{~b}$ & $4.10 \pm 0.38 \mathrm{e}$ & $340.63 \pm 1.12 \mathrm{~b}$ \\
Gabou of onion bulbs & $3.35 \pm 0.39 \mathrm{~cd}$ & $3.23 \pm 0.03 \mathrm{~d}$ & $0.86 \pm 0.01 \mathrm{~d}$ & $10.29 \pm 0.02 \mathrm{c}$ & $78.99 \pm 0.31 \mathrm{a}$ & $3.30 \pm 0.15 \mathrm{e}$ & $364.92 \pm 1.55 \mathrm{a}$ \\
\hline
\end{tabular}

There is no significant difference $(\mathrm{p}>0.05)$ between the averages that have the same letter in each colum

\subsubsection{Effect of Roasting Conditions on the Mineral Composition of Gabou}

Table 3 presented the mineral contents of flower stems, green leaves, onion bulbs and their Gabou. The contents expressed in $\mathrm{mg} / \mathrm{g}$ of $\mathrm{Ca}, \mathrm{K}, \mathrm{Mg}, \mathrm{Na}$ and $\mathrm{Zn}$ fluctuated from 1.73 to $3.19 ; 15.64$ to $17.86 ; 0.35$ to $1.66 ; 0.43$ to 1.09 and 0.020 to 0.028 respectively. 
Table 3. Mineral element contents of different vegetative parts of the onion and Gabou

\begin{tabular}{llcccc}
\hline & \multicolumn{1}{c}{$\mathrm{Ca}$} & $\mathrm{K}$ & $\mathrm{Mg}$ & $\mathrm{Na}$ & $\mathrm{Zn}$ \\
\cline { 2 - 6 } Products & \multicolumn{5}{c}{$\mathrm{mg} / \mathrm{g}$} \\
\hline Flower stems & $2.88 \pm 0.14 \mathrm{ab}$ & $16.89 \pm 0.02 \mathrm{ab}$ & $0.69 \pm 0.01 \mathrm{~b}$ & $0.58 \pm 0.08 \mathrm{~b}$ & $2.19 \pm 0.05 \mathrm{a}$ \\
Gabou of flower stems & $3.19 \pm 0.13 \mathrm{a}$ & $16.70 \pm 0.08 \mathrm{ab}$ & $0.65 \pm 0.02 \mathrm{~b}$ & $0.54 \pm 0.04 \mathrm{bc}$ & $2.09 \pm 0.09 \mathrm{a}$ \\
Green leaves & $2.83 \pm 0.07 \mathrm{ab}$ & $17.64 \pm 0.25 \mathrm{a}$ & $1.66 \pm 0.06 \mathrm{a}$ & $1.09 \pm 0.02 \mathrm{a}$ & $2.58 \pm 0.50 \mathrm{a}$ \\
Gabou of green leaves & $2.82 \pm 0.28 \mathrm{ab}$ & $17.50 \pm 0.09 \mathrm{a}$ & $1.57 \pm 0.07 \mathrm{a}$ & $1.02 \pm 0.01 \mathrm{a}$ & $2.11 \pm 0.29 \mathrm{a}$ \\
Onion bulbs & $1.77 \pm 0.09 \mathrm{~d}$ & $17.86 \pm 0.50 \mathrm{a}$ & $0.36 \pm 0.03 \mathrm{c}$ & $0.43 \pm 0.03 \mathrm{c}$ & $2.33 \pm 0.19 \mathrm{a}$ \\
Gabou of onion bulbs & $1.73 \pm 0.02 \mathrm{~d}$ & $17.23 \pm 0.29 \mathrm{a}$ & $0.35 \pm 0.02 \mathrm{c}$ & $0.43 \pm 0.01 \mathrm{c}$ & $2.44 \pm 0.19 \mathrm{a}$ \\
\hline
\end{tabular}

There is no significant difference ( $p>0.05$ ) between the averages that have the same letter in each column.

\subsubsection{Effect of Roasting Conditions on the $\mathrm{pH}$ of Gabou}

Table 4 showed the $\mathrm{pH}$ of flower stems, green leaves, onion bulbs and their Gabou. The analysis of this result revealed that the $\mathrm{pH}$ of Gabou varied from 4.45 to 5.22 and there was a significant difference $(\mathrm{p}<0.05)$ in $\mathrm{pH}$ between Gabou.

Table 4. $\mathrm{pH}$ of dried vegetative parts of onion and Gabou

\begin{tabular}{lc}
\hline Products & $\mathrm{pH}$ \\
\hline Flower stems & $4.88 \pm 0.00 \mathrm{c}$ \\
Gabou of flower stems & $4.45 \pm 0.04 \mathrm{f}$ \\
Green leaves & $5.07 \pm 0.00 \mathrm{~b}$ \\
Gabou of green leaves & $5.22 \pm 00 \mathrm{a}$ \\
Onion bulbs & $4.54 \pm 0.02 \mathrm{e}$ \\
Gabou of onion bulbs & $4.59 \pm 0.00 \mathrm{e}$ \\
\hline
\end{tabular}

There is no significant difference ( $p>0.05$ ) between the averages that have the same letter in each column.

\section{Discussion}

The transformation of onion into Gabou is a feminine activity. In general, in Africa, the processing of food products is women's business and it is an activity that is added to the agricultural work (Paulet, 1991). The major unit operations identified during the preparation of the different types of Gabou are bulbs crushing, green leaves pounding, solar drying, roasting, milling of roasted products and the condiment formulation.

Manual crushing using two stones applied by the producers leads to the production of coarse and heterogeneous crushed. This affects drying and roasting time (Johnson, Brennan, \& Yobo, 1998). Indeed, the drying of thick products is too slow and the inhibition of microorganisms may be incomplete (Rozis \& Guinebault, 1995). In addition to this, the dry crushed will not be roasted homogeneously. The use of mechanical crushers makes it possible to obtain medium and homogeneous crushed material. It also reduces the duration and the difficulty of manual stones crushing. In fact, crushing is one of the most difficult unit operations due to the sulphurous oils that emerge during this operation. These oils cause tearing and runny nose (Block, Naganathan, Putman, \& Zhao, 1993).

During the production of Gabou, producers use only solar drying. It is a cheap natural and simple drying system, however, less easy to manage compared to dehydration by improved means (Burden, \& Wills, 1992). The solar drying on the ground, used by the producers exposes the products directly to solar radiation, dust, insects and requires a long drying time. Hence the risk of quality deterioration, decay but also mold. In fact, direct exposure to the sun could lead to vitamin loss and browning (Rozis, \& Guinebault, 1995).

Traditional roasting in pots does not control either temperature or time. Gabou producers stop roasting only when they consider the amount of aroma released sufficient. A bad roasting not only slightly alters the organoleptic quality of a food but also leads to biochemical changes that are harmful to its nutritional quality (Schwartzberg, 2002; Oliviero, Capuano, Cammerer, \& Fogliano, 2009; Thidarat et al., 2016).

The sensory attributes of Gabou changes according to the degree of roasting. Many authors reported this change in the sensory attributes of foods during roasting (Bolek \& Ozdemir, 2017; Youn \& Chung, 2012; Uysal, Sumnu, \& Sahin, 2009; Fasasi, Eleyinmi, \& Oyarekua, 2007; Nebesny \& Budryn, 2006). The development of the best sensory attributes depends on roasting conditions (Buckholz, Daun, \& Stier, 1980; Yaacoub, 2009). According to many authors, temperature and time are considered the most important conditions of the roasting process. During this study, the best sensory attributes (aroma and color) were obtained at $120^{\circ} \mathrm{C}$ for 8 min for onion bulb Gabou, $120^{\circ} \mathrm{C}$ for $5 \mathrm{~min}$ for green leaf $\mathrm{Gabou}$ and $130^{\circ} \mathrm{C}$ for $11 \mathrm{~min}$ for stem Gabou in the presence of $1 \mathrm{ml}, 2 \mathrm{ml}$ and 0 
$\mathrm{ml}$ palm oil per $30 \mathrm{~g}$, respectively. It is important to note that, color is a crucial indicator that can be used as a quality control indicator during roasting processes (Özdemir \& Devres, 2000; Mendes, de Menezes, Aparecida, \& Da Silva, 2001). The aroma is also regarded as an important quality indicator of Gabou.

The physicochemical properties of foods are noticeably changed during the roasting process. Many published works have investigated the effect of roasting conditions on the properties of several products (Eke-Ejiofor \& Onyeso, 2019; Rabiou et al., 2018b; Marzocchi, 2017). The results of the proximate composition showed that the moisture content of Gabou was lower than that of various dried vegetative parts of the onion and the minimum recommended moisture content of $4 \%$ for dried onion (Rozis and Guinebault, 1995). It varied from 2.80 to $3.97 \%$. These values were also lower than those of Gabou traditionally obtained (Rabiou et al., 2018b). The Gabou prepared in the laboratory had lipid contents slightly higher than those of dried vegetative parts of the onion. The values obtained were in agreement with those of the Gabou traditionally obtained. However, during the production of Gabou traditionally lipid contents decreased. The lipid contents of Gabou produced in the laboratory were between 0.86 and $3.97 \%$. Carbohydrates contents had increased significantly $(\mathrm{p}<0.05)$ during Gabou production. The carbohydrate contents of Gabou ranged from 33.74 to $78.99 \%$. These values were significantly lower than those of Gabou traditionally produced. This can be explained by taking into account the fiber content in the calculating of the carbohydrate content. After roasting the energy loads of Gabou produced in the laboratory, varied from 273.02 to $364.92 \mathrm{kcal} / 100 \mathrm{~g}$, increased significantly $(\mathrm{p}<0.05)$ but remain low compared to those of Gabou traditionally produced. This is logical because the carbohydrate content to be reduced. Concerning the ash, protein and total fiber contents of the Gabou produced in the laboratory, they were slightly lower than those of dried vegetative parts of the onion. However, they corroborate those of Gabou traditionally produced (Rabiou et al., 2018b). Among the three Gabou studied, the green leaves Gabou had the highest nutrient contents, except for the carbohydrate content, whereas the bulbs Gabou had the lowest contents.

After roasting, the $\mathrm{pH}$ increased significantly and not significantly in the green leaves Gabou and bulb Gabou respectively. On the other hand, the $\mathrm{pH}$ decreased significantly at the level of Gabou of flower stems. Similar findings were reported by Sahin et al. (2009) and Yousif and Alghzawi (2000). The decrease in pH may be related to roasting conditions. Indeed, the Gabou of flower stem was prepared without the addition of oil and from a higher temperature $\left(130^{\circ} \mathrm{C}\right)$ and time $(11 \mathrm{~min})$ than the green leaves Gabou and bulb Gabou. Fikry et al. (2019) were observed that the increase in roasting temperature and time caused a decrease of the $\mathrm{pH}$ of brew. It was suggested that the decrease in the $\mathrm{pH}$ value might be attributed to the formation of acidic caramelization by-products, such as pyruvic acid, and the formation of acidic Maillard products during the roasting process (Yousif \& Alghzawi, 2000). Gabou can be classified as low acid spice ( $\mathrm{pH}>4.5)$.

The analysis of the results in Table 3 showed that roasting conditions did not had a significant influence $(\mathrm{p}>0.05)$ on the mineral content determined. However, except for the content of $\mathrm{Ca}$ in the Gabou of flower stems, a decreasing trend was observed in all Gabou. This differs from the increase observed, in general, in the Gabou obtained traditionally (Rabiou et al., 2018b). The Gabou obtained in the laboratory had the contents of $\mathrm{Ca}, \mathrm{K}$ (except in the green leaves Gabou), $\mathrm{Na}$ and $\mathrm{Zn}$ slightly lower than those of the Gabou traditionally obtained. Nevertheless, the Mg contents of the Gabou traditionally obtained were significantly higher than those of the Gabou obtained in the laboratory. This increase in levels is probably due to contamination and/or extensive roasting. The $\mathrm{K}$ and $\mathrm{Zn}$ contents of onion bulb studied were slightly higher than the contents reported previously (Ciqual, 2017). However, the $\mathrm{Ca}, \mathrm{Mg}$ and $\mathrm{Na}$ contents reported by Ciqual, (2017) were higher than the contents obtained.

Roasting conditions that led to the production of Gabou with better sensory characteristics did not have a significant negative influence $(\mathrm{p}<0.05)$ on proximate and mineral composition. On the contrary, they have significantly reduced the moisture content which contributed to the reduction of Gabou's shelf life.

\section{Conclusion}

The production of Gabou is an exclusively female activity and entirely artisanal. It was physically painful and tedious activity for the producers. The production of Gabou was an income-generating activity for producers and sellers. Unfortunately, it was unbanked and women producers receive no financial support. All parts of the vegetative apparatus of onion can be used in the production of Gabou. Roasting allowed the development of the aroma and color of Gabou. The optimal roasting conditions have been determined. These roasting conditions did not significantly affect the initial composition of the raw material.

\section{References}

AOAC. (1990). Official Method of Analysis of the Association of Official Analytical Chemist (15 ${ }^{\text {th }}$ ed.). Washington DC. 
AOAC. (2000). Official Method of Analysis of the Association of Official Analytical Chemist. Washington DC., USA.

Block, E., Naganathan, S., Putman D., \& Zhao, S. H. (1993). Organo sulfur chemistry of garlic and onion: Recent results. Pure \& Applied Chemistry, 65, 625-632. https://doi.org/10.1351/pac199365040625

Bolek, S., \& Ozdemir, M. (2017). Optimization of roasting conditions of Pistacia terebinthus in a fluidized bed roaster. LWT Food Science and Technology, 80, 67-75. https://doi.org/10.1016/j.lwt.2017.02.007

Boukary, H., Roumba, A., Adam, T., Barrage M., \& Saadou, M. (2012). Interactions entre la variabilité des écotypes de l'oignon (Allium cepa L.) et les facteurs agro-climatiques au Niger. Tropicultura, 30(4). Retrieved from http://www.tropicultura.org/text/v30n4.pdf\#page=19

Buckholz, L. L., Daun H., \& Stier, E. (1980). Influence of roasting time on sensory attributes of fresh roasted peanuts. Journal of Food Science, 45, 547-554. https://doi.org/10.1111/j.1365-2621.1980.tb04098.x

Burden, J., \& Wills, R. B. H. (1992). Prévention des pertes après récolte: Fruits, légumes, racines et tubercules. Collection FAO; formation $\mathrm{N}^{\circ}$ 17/2 Rome.

Ciqual, A. T. (2017). Composition nutritionnelle des aliments. Retrieved from: https://ciqual.anses.fr

D'Alessandro, S., \& Soumah, A. (2008). Évaluation sous régionale de la chaîne de valeurs oignon léchalote en Afrique de l'Ouest. Bethesda (MD, USA): projet ATP, Abt Associates Inc. Retrieved from https://www.reca-niger.org/IMG/pdf/Oignon_evaluation_chaine_de_valeurs_ATP_2008.pdf

De Lannoy, G. (2001). Oignon Allium cepa L. In R. H. Raemaekers (Eds), Agriculture en Afrique tropicale (pp. 518-526). Bruxelles: DGCI.

Eke-Ejiofor, J., \& Onyeso, B. U. (2019). Effect of Processing Methods on the Physicochemical, Mineral and Carotene Content of Orange Fleshed Sweet Potato (OFSP). Journal of Food Research, 8(3), 50-58. https://doi.org/10.5539/jfr.v8n3p50

Eplucher, O. (2010). L'importance de l'oignon dans la vie socio-économique du Niger: contexte et agendas d'action. Retrieved from: http://www.reca-niger.org/IMG/pdf/Importance_de_1_oignon.pdf

Fasasi, O., Eleyinmi, A., \& Oyarekua, M. (2007). Effect of some traditional processing operations on the functional properties of African breadfruit seed (Treculia africana) flour. LWT Food Science and Technology, 40, 513-519. https://doi.org/10.1016/j.lwt.2005.11.009

Fikry, M., Yusof, Y. A., Al-Awaadh, A. M., Rahman, R. A., Chin, N. L., Mousa, E., \& Chang, L. S. (2019). Effect of the Roasting Conditions on the Physicochemical, Quality and Sensory Attributes of Coffee-Like Powder and Brew from Defatted Palm Date Seeds. Foods, 8, 61. https://doi.org/10.3390/foods8020061

Foury, C., \& Schweisguth, B. (1992). L'oignon. In A. Gallais, \& H. Bannerot (Eds.), Amélioration des espèces végétales cultivées (pp. 406-419). Paris: INRA.

Fritsch, R. M., \& Friesen, N. (2002). Evolution, domestication and taxonomy. In H. D. Rabinowitch, \& L. Currah (Eds.), Allium crop science: recent advances (pp. 5-30). Wallingford, UK; New York, USA: CABI Publishing. https://doi.org/10.1079/9780851995106.0005

Johnson, P. N. T., Brennan, J. G., \& Addo, Y. F. Y. (1998). Air drying characteristics of plantain (Musa A.A.B). Journal of Food Engineering, 37, 233-242. https://doi.org/10.1016/S0260-8774(98)00076-4

MA. (2013). Résultats définitifs de l'enquête sur les productions horticoles 2012/2013. Retrieved from http://www.reca-niger.org/spip.php?article738

Marzocchi, S., Pasini, F., Verardo, V., Ciemniewska-Zytkiewicz, H., Caboni, M. F., \& Romani, S. (2017). Effects of different roasting conditions on physical-chemical properties of Polish hazelnuts (Corylus avellana L. var. Katalo 'nski). LWT Food Science and Technology, 77, 440-448. https://doi.org/10.1016/j.lwt.2016.11.068

Mendes, L. C., De Menezes, H. C., Aparecida M., \& Da Silva, A. (2001).Optimization of the roasting of robusta coffee (C. canephora conillon) using acceptability tests and RSM. Food Quality and Preference, 12, 153-162. https://doi.org/10.1016/S0950-3293(00)00042-2

Nebesny, E., \& Budryn, G. (2006). Evaluation of sensory attributes of coffee brews from robusta coffee roasted under different conditions. European Food Research and Technology, 224, 159-165. https://doi.org/10.1007/s00217-006-0308-y

Oliviero, T., Capuano, E., Cammerer B., \& Fogliano, V. (2009). Influence of roasting on the anti-oxidant activity and HMF formation of a cocoa bean model systems. Journal of Agricultural and Food Chemistry, 57(1), 
147-152. https://doi.org/10.1021/jf802250j

Özdemir, M., \& Devres, O. (2000). Analysis of color development during roasting of hazelnuts using response surface methodology. Journal of Food Engineering, 45, 17-24. https://doi.org/10.1016/S0260-8774(00)00036-4

Paulet, J. V. (1991). Amélioration des procédés traditionnels de transformation de certains oléagineux et du manioc en Afrique. Retrieved from http://www.fao.org/docrep/006/t8320f/t8320f00.HTM

PRODEX. (2009). Plan d'actions opérationnel de la filière oignon du Niger. Ministère du développement agricole. Retrieved from

http://www.recaniger.org/IMG/pdf/Nig_filiere_oignon_plan_actions_PRODEX_2009.pdf

PRODEX. (2012). Guide de bonnes pratiques de production, stockage Et conservation de l'oignon. Retrieved from http://www.fao.org/sustainable-food-value-chains/training-and-learning-center/details-materials/fr/c/429139

Rabiou, M. M., Moussa, I., Mella T., \& Sadou, H. (2018a). Panorama of Onion Production in Tillabéri, A Region of the Far West of Niger. European Scientific Journal, 14, 175-196. https://doi.org/10.19044/esj.2018.v14n15p175

Rabiou, M. M., Yaou, C., Lewamy M., \& Sadou, H. (2018b). Evolution of the Chemical Composition during the Fabrication of the Different Types of Gabou, a Traditional Onion-Based Spice Commonly Used in Niger. Journal of Food Processing \& Technology, 9, 748. https://doi.org/10.4172/2157-7110.1000748

Rozis, J. F., \& Guinebault, A. (1995). Sécher des produits alimentaires: Techniques, procédés, équipements. Groupe de recherche et d'échange technologiques (GRET). Retrieved from http://pmb.sicac.org/opac_css/doc_num.php?explnum_id=690. [Accessed 19 November2014].

Sahin, H., Topuz, A., Pischetsrieder, M., \& Özdemir, F. (2009). Effect of roasting process on phenolic, antioxidant and browning properties of carob powder. European Food Research and Technology, 230, 155. https://doi.org/10.1007/s00217-009-1152-7

Schwartzberg, H. G. (2002). Engineering and Food for the $21^{\text {st }}$, Century, chapter Modelling bean heating during batch roasting of coffee beans. CRC Press LLC, London, New York, Boca Raton. https://doi.org/10.1201/9781420010169.ch52

Tarchiani, V., Robbiati, G., \& Salifou, M. R. (2013). Filières oignon en Afrique de l'Ouest : étude comparée des filières nigérienne et béninoise. Cahiers Agricultures, 22, 112-23.

Thidarat, S., Udomsak, M., Jindawan, W., Namphung, D., Suneerat, Y., Sawan T., \& Pisamai, T. (2016). Effect of roasting on phytochemical properties of Thai soybeans. International Food Research Journal, 23(2), 606-612.

Uysal, N., Sumnu, G., \& Sahin, S. (2009). Optimization of microwave-infrared roasting of hazelnut. Journal of Food Engineering, 90, 255-261. https://doi.org/10.1016/j.jfoodeng.2008.06.029

Watts, B. M., Ylimaki, G. L., Jeffery L. E., \& Elias, L. G. (1991). Méthodes de base pour l'évaluation sensorielle des aliments. CRDI, Ottawa, ON, CA. Retrieved from https://idl-bnc-idrc.dspacedirect.org/bitstream/handle/10625/3774/IDL-3774.pdf?sequence=1

Yaacoub, R. (2009). Nutritional and sanitary impact of nuts and seeds roasting: the interest of using fuorescence spectroscopy as a tool to control neoformed compounds. Chemical Sciences AgroParisTech. Retrieved from https://pastel.archives-ouvertes.fr/pastel-00005932/document

Youn, K. S., \& Chung, H. S. (2012) Optimization of the roasting temperature and time for preparation of coffee-like maize beverage using the response surface methodology. LWT Food Science and Technology, 46, 305-310. https://doi.org/10.1016/j.lwt.2011.09.014

Yousif, A. K. \& Alghzawi, H. (2000). Processing and characterization of carob powder. Food Chemistry, 69, 283-287. https://doi.org/10.1016/S0308-8146(99)00265-4

\section{Copyrights}

Copyright for this article is retained by the author(s), with first publication rights granted to the journal.

This is an open-access article distributed under the terms and conditions of the Creative Commons Attribution license (http://creativecommons.org/licenses/by/4.0/). 